\title{
Análise da cadeia produtiva da carne bovina no Município de Dianópolis, Tocantins
}

\author{
Analysis of the beef production chain in the Municipality of Dianópolis, Tocantins \\ Análisis de la cadena de producción de carne vacuna en el Municipio de Dianópolis, Tocantins
}

Recebido: 28/12/2020 | Revisado: 28/12/2020 | Aceito: 27/02/2021 | Publicado: 06/03/2021

\author{
Tamires Rodrigues Nunes \\ ORCID: https://orcid.org/0000-0001-8300-0388 \\ Universidade Estadual do Tocantins, Brasil \\ E-mail: tamires63dno@hotmail.com \\ Josivaldo Alves da Silva \\ ORCID: https://orcid.org/0000-0002-8160-4011 \\ Universidade Estadual do Tocantins, Brasil \\ E-mail: josivaldoadm@yahoo.com.br
}

\begin{abstract}
Resumo
Uma cadeia produtiva refere-se ao conjunto de etapas sucessivas de operações interligadas pelas quais diversos insumos passam por algum processo de transformação até a composição de um produto final. Esse artigo tem o objetivo de estudar a gestão da cadeia produtiva da carne bovina do Município de Dianópolis/TO, a partir da análise das atividades de transporte, beneficiamento, processamento, comercialização e distribuição até o cliente final, no período entre $1^{\circ}$ de fevereiro a 30 de outubro de 2020. A pesquisa tem o caráter descritivo e exploratório, a metodologia escolhida é qualitativa e quantitativa, realizada através de pesquisa bibliográfica, documental, de campo e estudo de caso. Os instrumentos de coletas de dados foram; dois questionários, o primeiro estruturado, misto com dez questões, aplicado a 13 produtores criadores de bovinos de Dianópolis, o segundo semi-estruturando, com cinco perguntas abertas, enviado á gerente do Abatedouro. Os questionários foram enviados para o e-mail dos participantes da pesquisa com a utilização do formulário Google forms. As entrevistas foram realizadas no período compreendido entre 10 a 30 de outubro de 2020. No estudo constatou-se que o Município de Dianópolis, conta com 543 produtores. 553 propriedades rurais e 52.844 cabeças de bovinos, $76,92 \%$ dos produtores entrevistados afirmaram que comercializam os bovinos para o abatedouro local. O processamento de produção da carne bovina é o transporte, descanso, lavagem, pendura sangria, esfola, evisceração, cortes da carcaça, refrigeração, corte e desossa, embalagem, estocagem e expedição da carne.

Palavras-chave: Cadeias produtivas; Transporte de animais; Administração da produção.
\end{abstract}

\begin{abstract}
A production chain refers to the set of successive stages of interconnected operations through which different inputs undergo some transformation process until the composition of a final product. This article aims to study the management of the beef production chain in the Municipality of Dianópolis / TO, from the analysis of transportation, processing, processing, marketing and distribution activities to the final customer, in the period from February 1st to October 30, 2020. The research has a descriptive and exploratory character, the methodology chosen is qualitative and quantitative, carried out through bibliographic, documentary, field and case study research. The data collection instruments were; two questionnaires, the first structured, mixed with ten questions, applied to 13 cattle breeders in Dianópolis, the second semi-structured, with five open questions, sent to the Slaughterhouse manager. The questionnaires were sent to the participants' e-mail using the Google forms. The interviews were carried out in the period between 10 and 30 October 2020. In the study it was found that the Municipality of Dianópolis, has 543 producers. 553 rural properties and 52,844 cattle heads, $76.92 \%$ of the interviewed producers stated that they sell the cattle to the local slaughterhouse. The processing of beef production is the transportation, rest, washing, hanging of bleeding, skinning, evisceration, cuts of the carcass, refrigeration, cutting and deboning, packaging, storage and shipping of the meat.
\end{abstract}

keywords: Production chains; Transport of animals; Production management.

\section{Resumen}

Una cadena de producción se refiere al conjunto de etapas sucesivas de operaciones interconectadas a través de las cuales diferentes insumos sufren algún proceso de transformación hasta la composición de un producto final. Este artículo tiene como objetivo estudiar la gestión de la cadena de producción de carne vacuna en el Municipio de Dianópolis /TO, desde el análisis de las actividades de transporte, procesamiento, procesamiento, comercialización y distribución hasta el cliente final, en el período del 1 de febrero al 30 de octubre de 2020. La investigación tiene un carácter descriptivo y exploratorio, la metodología elegida es cualitativa y cuantitativa, realizada a través de investigaciones bibliográficas, documentales, de campo y de estudio de caso. Los instrumentos de recolección de datos fueron; dos cuestionarios, el primero estructurado, mezclado con diez preguntas, aplicado a 13 ganaderos de 
Dianópolis, el segundo semiestructurado, con cinco preguntas abiertas, enviado al gerente del Matadero. Los cuestionarios se enviaron al correo electrónico de los participantes utilizando los formularios de Google. Las entrevistas se realizaron en el período comprendido entre el 10 y el 30 de octubre de 2020 . En el estudio se encontró que el Municipio de Dianópolis, cuenta con 543 productores. 553 predios rurales y 52,844 cabezas de ganado, el $76,92 \%$ de los productores entrevistados manifestaron que venden el ganado al matadero local. El procesamiento de la producción de carne vacuna es el transporte, reposo, lavado, colgado de sangrado, desollado, eviscerado, cortes de la canal, refrigeración, corte y deshuesado, envasado, almacenamiento y envío de la carne.

Palabras clave: Cadenas productivas; Transporte de animales; Gestión de la producción.

\section{Introdução}

A gestão de uma cadeia produtiva trata-se da aplicação de é um conjunto de etapas consecutivas de procedimentos operacionais envolvendo o transporte dos insumos, a transformação, constituição de um produto final e manuseio até o cliente final. A transformação da matéria-prima de forma adequada exige a aplicação de ferramentas da administração da produção como uma atividade gerencial orientada para a transformação de insumos em um bem físico ou serviço, por meio da implementação de técnicas de gerenciamento de processos produtivos, com a finalidade de produzir produtos ou serviços.

Nesse sentido, Silva (2005) define cadeia produtiva como um conjunto de elementos que interagem em um processo produtivo para oferta de produtos ou serviços ao mercado consumidor de modo que possibilita visualizar de forma integral; identificar as debilidades e potencialidades; motivar o estabelecimento de cooperação técnica; identificar gargalos e elementos faltantes; incrementar os fatores condicionantes de competitividade em cada segmento. Na prática, a operacionalização dos elementos de beneficiamento e processamento de uma cadeia produtiva, ocorre através da aplicação dos fundamentos da administração da produção.

Nesse aspecto, administração da produção refere-se a atividade de gerenciar os recursos destinados à produção e disponibilização de bens e serviços, transformando as organizações em um sistema ao qual envolve vários setores operando e produzindo resultados que por sua vez, devem satisfazer os objetivos estratégicos da empresa e consequentemente a satisfação do cliente (Slack et al. 2009).

Assim sendo, a gestão da cadeia produtiva de carne bovina refere-se na aplicação de fundamentos de planejamento, organização, comando e controle, em um conjunto de componentes interativos, com diferentes sistemas produtivos, envolvendo de forma integrada, fornecedores de serviços e insumos, indústrias de processamento e transformação, distribuição e comercialização de produtos e subprodutos, e seus respectivos consumidores finais.

Certamente, o interesse por esse campo de estudo surgiu mediante a percepção da inexistência de pesquisas acadêmicas a respeito do gerenciamento da cadeia produtiva da carne bovina no Município de Dianópolis/TO, a partir da análise das atividades de transporte, beneficiamento, processamento, comercialização e distribuição até o cliente final. Tudo isso, foram os fatores preponderantes para produção deste artigo científico com essa temática. Dessa forma, a principal motivação para a escolha do Município de Dianópolis, como local para realização desse estudo, surgiu a partir da identificação de outras pesquisas acadêmicas semelhantes realizadas em outros municípios.

Esses estudos preliminares, reforçam a necessidade de uma análise das variáveis que ocorrem no processo de gerenciamento da cadeia produtiva da carne bovina no Município de Dianópolis, tomando conhecimento das estratégias adotadas do início ao fim. Nesse aspecto, o presente trabalho justifica-se pelo crescimento da produção da carne bovina em Dianópolis e Região nos últimos anos, fato que chamou a atenção não apenas de criadores e consumidores, mas também de investidores neste período. Desta forma, a produção de carne bovina ganhou uma grande importância para o Estado do Tocantins, tornando-se importante pesquisar todo o processo de planejamento e execução do transporte, armazenamento e abate, desde o local de origem até o ponto de distribuição e entrega ao consumidor final. 
Diante disso, este estudo tem enquanto relevância acadêmica e social, a premissa de que a pesquisa é considerada pioneira no local escolhido, e a partir de seus resultados publicados poderão servir de embasamento científico para a tomada de decisões que provoque mudanças estruturais em todo o sistema que envolve a cadeia produtiva da carne bovina no Município de Dianópolis.

Por certo, espera-se que através dessa pesquisa o segmento pecuário de Dianópolis e Região, a Agência de Defesa Agropecuária (ADAPEC) e o poder público local, possam ressignificarem seus conceitos acerca da garantia de produção de carne bovina de qualidade durante o ano todo como resultado do esforço conjunto de toda cadeia, e com isso quebrar as barreiras para celebração de parcerias, integrações e alianças mercadológicas entre os diversos componentes, e assim contribuir para o aumento do Produto Interno Bruto (PIB) do ramo pecuário do Tocantins.

Portanto, análise da cadeia produtiva da carne bovina no Município de Dianópolis no período de $1^{\circ}$ de fevereiro a 30 de agosto de 2020. Parti-se da seguinte questão-problema de "como ocorrem às atividades de transporte, beneficiamento, processamento, distribuição e comercialização da carne bovina no Município de Dianópolis/TO?”. A hipótese é “as atividades de transporte da propriedade até o abatedouro, o beneficiamento, processamento, comercialização e distribuição da carne bovina no Município de Dianópolis/TO, até o cliente final ocorre de acordo com as normas estabelecidas pelos órgãos de controle e fiscalização". O objetivo geral é estudar a gestão da cadeia produtiva da carne bovina do Município de Dianópolis/TO, a partir da análise das atividades de transporte, beneficiamento, processamento, comercialização e distribuição até o cliente final, no período entre $1^{\circ}$ de fevereiro a 30 de outubro de 2020.

Este artigo está estruturado na seguinte ordem: a primeira parte aborda os aspectos teóricos inerentes as produtivas, logística, transporte rodoviário, transporte de animais bovinos para o abate, ao passo que a segunda seção apresenta os fundamentos e conceitos da administração da produção, fechando a parte conceitual para posteriormente, expor a metodologia aplicada no trabalho, seguida os resultados, análise e considerações finais.

\subsection{Cadeias produtivas}

De modo geral, as cadeias produtivas são estudadas sob aspectos da preocupação com a sucessão de operações integradas, relacionadas a logística, estratégias de armazenamento e escolha de parceiros. Nessa perspectiva, Kondo (2007) define cadeia produtiva como um conjunto de componentes interativos do qual fazem parte sistemas produtivos, fornecedores de insumos e serviços, indústrias de processamento e transformação, agentes de distribuição e comercialização, além dos consumidores finais.

Em outras palavras, Zilbersztajn (2000) afirma que a cadeia produtiva é uma sequência de operações que conduzem à produção de bens. A articulação dessas cadeias é influenciada pela fronteira de possibilidades estabelecidas pela tecnologia, além de ser definida pelas estratégias dos agentes que buscam a maximização de seus lucros. As relações entre os agentes são de complementaridade e são definidas por forças hierárquicas, o que torna a cadeia um sistema capaz de assegurar sua própria transformação.

Conforme a concepção de Batalha (1995), a integração cadeia produtiva de forma articulada demanda conhecimento e tecnologias, com o intuito de reduzir o impacto das limitações de seus atores sociais ou melhorar a qualidade e a eficiência produtiva, beneficiando assim o consumidor final e os demais grupos de atores sociais da cadeia.

Em termos práticos, a cadeia produtiva se articula entre diversas fases do processo produtivo, que envolve desde insumos básicos, a produção, distribuição, comercialização e colocação do produto final ao consumidor, compõem elos de uma corrente, sendo que esses elos são denominados de cadeia produtiva (Malafaia et al, 2009). 
Dessa forma, cadeia produtiva refere-se a um conjunto de atividades que se articulam progressivamente desde os insumos e equipamentos básicos da atividade da produção agrícola, pecuária e pesqueira beneficiamento e processamento, até o produto final, incluindo a distribuição e comercialização (Castro, 2009).

Além do mais, Batalha (1997) afirma que, as cadeias produtivas são a soma de todas as operações de produção e comercialização que foram necessárias para passar de uma ou várias matérias-primas de base a um produto final, isto é, até que o produto chegue às mãos de seu usuário, seja ele um particular ou uma organização.

Em outros termos, Staatz (1997) afirma que as cadeias produtivas devem ser integradas e fundamenta-se se em cinco conceitos básicos: verticalidade, pelo qual os elos são influenciados mutuamente; orientação pela demanda, que por sua vez gera as informações que determinam os fluxos de produtos e serviços; coordenação dentro dos canais, estabelecendo relações verticais dentro dos canais de comercialização, seja por meio de contratos ou mercado aberto; competição dos canais, considerando-se que o sistema pode envolver mais de um canal de produção, transformação e comercialização, alavancagem, pois, visa identificar pontos-chaves na sequência produção-consumo.

Portanto, pode-se deduzir que, os conceitos de cadeias produtivas trata-se da operacionalização de um conjunto de atividades que se articulam desde a definição dos insumos básicos, processamento, comercialização e distribuição dos produtos ao cliente final.

\subsection{Cadeia produtiva da carne bovina no Brasil}

A cadeia de carne bovina ocupa posição de destaque no contexto da economia rural brasileira, ocupando vasta área do território nacional e respondendo pela geração de emprego e renda de milhões de brasileiros. Trata-se da integração de um conjunto de agentes que a compõe apresenta grande heterogeneidade envolvendo pecuaristas altamente capitalizados a pequenos produtores, frigoríficos com alto padrão tecnológico, capazes de atender a uma exigente demanda externa, a abatedouros que dificilmente preenchem requisitos mínimos da legislação sanitária (Brasil, 2007).

O Brasil é referência na produção de carne bovina, de acordo é considerado o maior exportador de carne bovina no mundo. Embora os maiores rebanhos bovinos do mundo pertençam à Índia, Brasil e China respectivamente, os Estados Unidos o quarto colocado em quantidade de gado do planeta, que ocupa o topo de maior produtor do mundo (CNA, 2016).

Assim sendo, a cadeia produtiva da carne bovina é o conjunto de elos interativos, compreendendo os sistemas produtivos agropecuários e agro-florestais, fornecedores de serviços e insumos, indústrias de processamento e transformação, distribuição e comercialização, além de consumidores finais de produtos e subprodutos dessa cadeia (Tirado et al. 2009).

\subsubsection{Cadeia produtiva da carne bovina do Tocantins}

Criado pela Constituição Federal de 1988, quando lideranças do norte goiano mobilizaram a população na busca da independência política da região, o Tocantins é o Estado mais novo do Brasil, atualmente com 32 anos de existência. O Estado possui uma vocação natural para o agronegócio, estando inserida em uma das últimas fronteiras agrícolas do País, a região conhecida como MATOPIBA (Fenandes \& Neves, 2018).

Dessa forma, metade do território do Estado do Tocantins tem potencial para a produção agrícola. A disponibilidade de recursos naturais, como água, biodiversidade, insolação e clima tropical, conferem ao Tocantins um meio físico, extremamente favorável à agropecuária. Prova disso é o fato de o Estado ocupar $11^{\circ}$ posição no rebanho bovino nacional. Esse rebanho se distribui em seus 8 milhões de hectares de áreas de pastagem, resultando em uma taxa de lotação de pouco mais de uma cabeça por hectare (IBGE, 2018). Uma vez que, o acesso a mercados internacionais é de suma importância para as cadeias produtivas, tendo em vista o valor agregado que o mercado externo pode pagar e a sua diversificação. A pauta de exportações 
do Estado do Tocantins consiste basicamente em produtos agropecuários, com uma participação expressiva da carne bovina. Do valor total exportado em 2016, $18 \%$ à carne desossada (Fenandes \& Neves, 2018).

Em suma, a cadeia da carne bovina ocupa posição de destaque no contexto da economia brasileira e consequentemente do Tocantins, ocupando vasta área coberta de pastagens, respondendo por uma fatia significativa da geração de emprego, trabalho e renda as pessoas que atuam de forma direta, ou indireta ao mercado do agronegócio. Uma das etapas da cadeia produtiva da carne bovina é a movimentação é o planejamento e execução do transporte e armazenamento dos produtos denominado de logística.

\subsubsection{Logística}

Em linhas gerais o conceito de logística está relacionado ao processo de planejamento e execução do eficiente transporte e armazenamento dos produtos, desde o ponto de origem até o ponto de consumo. De acordo Duarte (2011), o termo logístico trata-se da técnica identificadora de necessidades e características do consumo, na qual os indivíduos interagem na criação do bem ou do serviço, com objetivo de atender suas idealizações com eficácia, de maneira segura e rápida. Para qualquer empresa é indispensável, pois, organiza o fluxo de produtos e dos serviços.

Além disso, Ballou (2012), afirma que, a logística trata de trata-se de um conjunto de atividades de movimentação e armazenagem que facilitam o fluxo de produtos desde o ponto de aquisição da matéria-prima até o ponto de consumo final, assim como dos fluxos de informação envolvidos no processo de movimentação do produto.

Nesse sentido, a logística tem entre suas funções, a responsabilidade de planejar, administrar e coordenar, a compra das matérias-primas, assim como organizar o seu armazenamento, transporte e distribuição. Novaes (2007) acrescenta que sem a logística as metas das empresas não podem ser atingidas conforme o planejamento realizado. Na mesma linha, Ballou (1993) enfatiza que a logística empresarial trata de todas essas atividades com o intuito de facilitar o fluxo dos produtos, e proporcionar serviços adequados aos clientes com custo razoável. É uma ótima ferramenta a ser utilizada quando se trata de competividade, vista como elemento integrador das relações em presas.

Em suma, a logística possui atividades primárias sendo elas: o transporte, manutenção de estoques e o processamento de pedidos. A integração delas é crucial para que se obtenha um serviço adequado, um dos motivos para que se tenha um profissional capacitado para lidar com essa demanda dentro da empresa (Ballou, 2012). Nesse aspecto, o transporte é um componente da logística.

\subsubsection{Transportes}

A definição de transporte é o movimento de pessoas e mercadorias entre locais em diversas categorias, características ao nível, veículos e operações. O transporte caracteriza-se como uma das fases mais importantes de todo o processo logístico, que inicia com a coleta e locomoção da matéria-prima até a indústria, e movimentação no interior da empresa. $\mathrm{O}$ transporte pertence a uma série de atividades que, quando reunidas e gerenciadas de forma conjunta e interligadas, constituem a base da logística empresarial (Ballou, 2012).

No Brasil, os serviços de transporte têm papel fundamental no processo de desenvolvimento econômico com efeitos diretos tanto sobre a produção quanto sobre o consumo no país. No que se refere à produção, a eficiência no transporte tem efeito redutor de custos semelhante ao do emprego de uma nova tecnologia na produção ou de redução do custo de uma matéria-prima fundamental para a atividade econômica. Sobre o consumo, a redução dos custos com transporte diminui os preços dos bens finais, resultando em um aumento de poder de compra da população. O resultado disso é o aumento da demanda por bens e serviços no mercado, o que impulsiona a atividade produtiva (CNT, 2017). 
Em resumo, o principal modo de transporte de pessoas e cargas no país, o transporte rodoviário dispõe de uma infraestrutura com qualidade inadequada e quantidade insuficiente, de modo que a eficiência do serviço é afetada negativamente. Como efeitos adversos da qualidade das rodovias disponíveis no país, contribuindo para o aumento do custo operacional do transporte, a maior probabilidade de ocorrência de acidentes rodoviários e, ainda, impactos ambientais.

\subsubsection{Transporte Rodoviário}

O transporte rodoviário é feito através de vias, como estradas, rodovias e ruas, as quais podem ser asfaltadas ou não, para deslocar cargas, pessoas e animais para diversos lugares. No Brasil. O modal rodoviário é predominante, fornece serviços para todos os setores de atividade econômica por meio do deslocamento de cargas e de trabalhadores e, também, das mercadorias destinadas ao consumo das famílias. Isso implica que a demanda do transportador advém de praticamente todas as áreas do sistema econômico-social brasileiro (CNT, 2017).

Portanto, o transporte rodoviário no país possui um papel relevante devido à falta de investimentos em outros modais, maior oferta, dimensão geográfica do Brasil, pode ser mais dinâmico e ágil, pois, possibilita rotas alternativas e permite ir aonde outros meios de transporte não chegam. Responde por aproximadamente $60 \%$ do total de cargas movimentadas. Sua frota transporta desde simples encomendas até safras inteiras, abastecendo as cidades e viabilizando o desenvolvimento econômico do país (Valente, 1997).

\subsubsection{Transportes de animais bovinos para o abate.}

O transporte dos animais ao estabelecimento de abate apresenta efeitos significativos na qualidade da carne, pois em condições desfavoráveis o sistema de transporte poderá levar à morte dos animais e ser responsável pelas principais contusões observadas na inspeção (Roça, 2001).

Além disso, Filho e Silva (2004) afirmam que, o transporte é considerado o evento mais estressante para os bovinos. Os caminhões são as principais formas de transporte dos bovinos para o abate na maioria dos países produtores de carne bovina. Sendo assim, após o embarque é necessário observar certos aspectos como: a densidade de carga do caminhão, tempo de viagem até o abatedouro, tempo de restrição alimentar e de água, condições ambientais da viagem e temperatura.

Certamente, após a porteira, o primeiro passo determinante na qualidade da carne bovina é o manejo pré-abate, que começa com o sistema de transporte dos animais das fazendas aos frigoríficos. Além da troca das longas viagens a pé (tropas de gado) pelas rápidas viagens de caminhão, o avanço no bem-estar dos animais durante o manejo pré-abate vai muito além da melhora nas condições físicas dos caminhões boiadeiros (Embrapa, 2020).

No caso do Tocantins, a cadeia de carne bovina é altamente dependente das rodovias, tanto para o transporte de animais das fazendas aos abatedouros, quanto para o acesso ao mercado interno ou escoamento da produção até os portos exportadores. O transporte de animais vivos, seja para abate em frigoríficos do Estado ou para movimentações interestaduais, é feito majoritariamente em caminhões que possuem capacidade média de 25 cabeças de boi e necessitam da Guia de Transporte Animal (GTA) em todas as movimentações (Fernandes \& Neves, 2018).

De fato, a GTA foi instaurada a partir do decreto $\mathrm{n}^{\circ}$ 5.741, de 30 de março de 2006, sendo que hoje figura como a principal documentação referente ao trânsito de animais no país. No Tocantins, a Adapec é o órgão autorizado a emitir a GTA. A agência possui unidades de atendimento nos 139 municípios tocantinenses, além de 77 escritórios locais, 30 barreiras fixas, 18 barreiras volantes e 10 barreiras fluviais. Após o abate, a carne produzida pela agroindústria segue ou para o mercado interno, ou para a exportação. Para exportação, a carne sai dos frigoríficos em contêineres refrigerados, utilizando majoritariamente o modal rodoviário, até o porto de destino (Fernandes \& Neves, 2018). GTA é um documento sanitário que garante o status de rastreabilidade dos animais, informações de origem e destino, bem como a finalidade do transporte. Cada 
espécie possui uma norma específica para a emissão da GTA. Por isso, a partir deste ponto, apresentam-se os debates em torno das definições acerca daquilo que se entende como administração da produção.

\subsubsection{Administração da produção}

A administração da produção pode ser caracterizada como uma atividade orientada para a produção de um bem físico ou para a prestação de um serviço, tendo como função administrativa a responsabilidade pela aplicação de técnicas de gerenciamento da produção adequada para executar o planejamento do projeto.

Nesse sentido, administração da produção é a maneira pela qual as organizações produzem bens e serviços para cumprir a sua missão no mercado que atua, ela está ligada a todos os setores de uma empresa e também à vida das pessoas. Trata-se de uma atividade definida para gerenciar os recursos destinados à produção e à disponibilização de bens e serviços (Slack; et al, 2009).

Na mesma linha, Côrrea et al, (2008) afirmam que, a administração de produção permite traçar com antecedência as necessidades futuras, o que contribui para obter firmeza no processo de decisões. Desta maneira, os materiais que serão adquiridos devem estar disponíveis para utilização no período correto, em quantidade correta para atender a demanda, com isso mantém o nível de custo com material reduzido, proporcionando à organização o não excesso com custos de compras.

Dessa forma, administração da produção soma os interesses estratégicos aos operacionais da empresa, fazendo com que ocorra o entendimento das necessidades de produção, para assim, o administrador alocar os recursos necessários para o alcance do produto final conforme programado e para que isto ocorra da melhor maneira envolve-se o planejamento e controle da produção, lidando com disponibilidade de materiais, verificação da mão de obra e capacidade produtiva, análises constantes dos cenários da produção, realizando previsões das reais necessidades (Harding, 1981).

Para Corrêa e Corrêa (2011) a administração da produção é a atividade de gerenciamento estratégico dos recursos humanos, materiais e tecnológicos, que promovem a interação dos processos que produzem e entregam bens e serviços visando atender necessidades ou desejos de qualidade, tempo e custo de seus clientes.

Do mesmo modo, a administração da produção como a soma dos interesses estratégicos aos operacionais da empresa, para atender as necessidades de produção, alocar os recursos materiais, a mão de obra para que seja atingido o produto final em conformidade com o planejamento estabelecido. Dessa forma, todas as organizações que possuem atividades produtivas com entrada de matérias para produção e que envolve os esforços de trabalho e transformação até a saída do produto final, precisam preocupar-se com os níveis de estoques, para evitar a ausência ou excessos dos materiais e com isso, disponibilizar apenas o essencial (Slack et al, 2009).

De acordo Côrrea et al, (2008) a execução dos processos produtivos de forma planejada evita, turbulências de prazos não cumpridos, isso não só de novo pedido, mas também de pedidos anteriores existentes, evitando que gere problemas em relação à capacidade de produção e atendimento da demanda, já que a força das vendas pode agir de maneira desregulada pela falta ou falha no planejamento da produção.

Dessa forma, a administração da produção é delineada pelo planejamento e controle da produção. Visto que, no processo de elaboração do planejamento, o administrador deve responder as seguintes questões: O que produzir e comprar? Quanto produzir e comprar? Quando produzir e comprar? Com que recursos produzir? A administração da produção trata da maneira pela qual as organizações produzem bens, serviços e esta ligada a todos os setores de uma empresa (Slack et al, 2009).

\subsubsection{Planejamento e controle da produção}

Planejamento e controle da produção, conhecido (PCP) é um conjunto de funções e atividades desenvolvidas no delineamento de metas e estratégias, formulação de planos, administração dos recursos humanos, físicos e acompanhamento 
para o ajustamento de possíveis desvios, compreendendo planos realizados nos âmbitos estratégicos, tático e operacional. De acordo Machline (1972), o PCP é função administrativa, que tem o objetivo principal de elaborar planos e atividades que orientem a produção e sirva de manual do controle e defina o que, quando, quanto, onde e como vai ser produzido e quem irá produzir.

Em outras palavras, Russomano (1979) identifica de maneira diferente, como um apoio de coordenação das várias atividades de produção, para que os programas desenvolvidos possam ser atendidos com economia e eficiência. Harding (1981) afirma que PCP, é um sistema processador de informações que facilita as decisões sobre várias etapas do processo produtivo, é elemento transformador e busca a partir de insumos básicos, produtos que satisfaçam, ou excedam as necessidades dos consumidores. O planejamento da produção é constituído do conjunto de atividades que antecedem e alimentam a programação e o controle da produção. A etapa envolve atividades dos projetos do produto, do processo e estimativa das quantidades que serão produzidas.

O PCP gerencia informações advindas de diversas áreas do sistema de produção, uma vez que exerce um papel, coordenação de apoio a todo o sistema. O PCP de forma direta, ou de forma indireta, relaciona-se praticamente com todas as funções deste sistema (Tubino, 2000). Dessa forma, o PCP é o conjunto de medidas destinadas a assegurar que a produção das peças encomendadas se faça nos prazos desejados. Compreende o planejamento e gerenciamento do estoque de matéria-prima, a programação das ordens de fabricação, serviço e a fiscalização da execução do planejado (Russomano, 1979).

Portanto, uma das ferramentas utilizadas para dinamizar o sistema de produção se refere ao PCP, que determina diferentes planejamentos para os diferentes níveis hierárquicos e, além disso, preconiza a integração de diversas áreas com a produção. A fim de atingir os seus objetivos, o PCP gerencia informações advindas de diversas áreas do sistema de produção, uma vez que exerce um papel, coordenação de apoio a todo o sistema. Assim, o PCP de forma direta, ou de forma indireta, relaciona-se praticamente com todas as funções deste sistema (Tubino, 2007).

\subsubsection{Processo de produção da carne bovina}

O processo da produção da carne bovina deve ser realizado em um local devidamente adequado para atender as normas técnicas, seja frigorífico ou abatedouro, o abate dos animais deve seguir as etapas. Nesse sentido, Roça (2002) afirma que, a aplicação de procedimentos técnicos e científicos no processamento da produção da carne bovina é de fundamental importância para se conseguir um ótimo desempenho no bem estar animal e na qualidade da carne. Assim, o abate humanitário inicia se na saída da porteira da propriedade, no embarque dos animais para o transporte com destino ao local de abate, com os devidos cuidados para causar e menos estresse.

Por certo, a boa qualidade do produto final derivado da carne bovina está diretamente ligada com os fatores de manejo que ocorrem durante a captura, embarcação, transporte, processamento. 
Figura 1: Processo de gestão da cadeia produtiva da carne bovina.

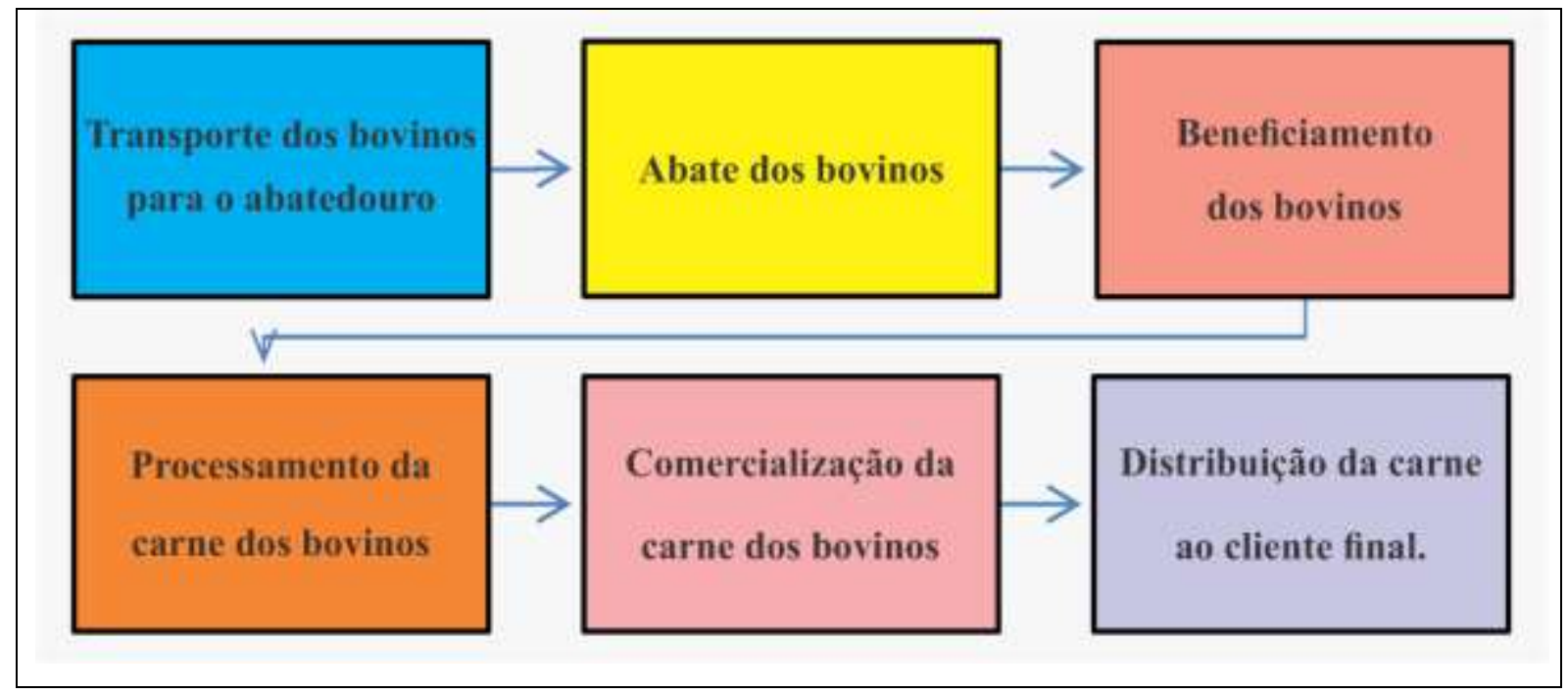

Fonte: Autores.

O processamento de produção da carne bovina inicia-se no campo, passa pelo transporte, a desossa das carcaças é realizado no próprio frigorífico que abate os animais, em entrepostos especializados em desossa ou nos açougues. Independentemente do local onde é feita, essa etapa é determinante nos quatro tipos de qualidade da carne: visual, gustativa, nutritiva e higiênico-sanitária (EMBRAPA, 2020). As etapas de produção da carne bovina, em forma de cadeia produtiva se constituem pelo encadeamento de ligações entre o transporte, abate, beneficiamento, processamento, comercialização e distribuição do produto ao consumidor final.

O transporte é o componente principal do sistema logístico da cadeia da carne bovina, ao qual se inicia na embarcação dos animais dentro da porteira, assim como o manejo com destino ao local de abate e encerrando seu ciclo na entrega dos produtos ao consumidor final. De forma geral, o motorista é o responsável pelos animais desde o embarque até a chegada no destino (Brasil, 2013).

O abate de bovinos é a aplicação de um conjunto de diretrizes técnicas e científicas que garantam o bem-estar dos animais desde a recepção no frigorífico ou abatedouro até a operação final seguindo as etapas de recepção, inspeção, descanso e dieta hídrica, lavagem, insensibilização, pendura, sangria. O beneficiamento e processamento ocorrem na esfola, evisceração, serragem das carcaças, refrigeração, cortes e desossa, embalagem, estocagem e expedição (EMBRAPA, 2020).

Como últimas etapas da cadeia, ocorrem a comercialização da carne bovina compreende a aplicação de um conjunto de atividades envolvendo vendedores e compradores que inicia no ponto de produção inicial e na transferência até que atinjam o consumidor final. A distribuição compreende a execução de um conjunto de operações de transporte e entrega com o objetivo de suprir os pontos de vendas, após o processo de produção, beneficiamento e comercialização da carne (Brasil, 2013).

\section{Metodologia}

Este trabalho, de caráter descritivo e exploratório, empregado no paradigma positivista e interpretativista. Dessa forma, a metodologia escolhida é essencialmente qualitativa e quantitativa, realizada por intermédio de pesquisa, bibliográfica, documental, de campo e estudo de caso por meio da aplicação de questionários. A execução da pesquisa foi dividida em oito principais etapas: no primeiro plano, realizou-se a investigação bibliográfica por meio da busca em Sites de periódicos 
científicos, repositórios de dissertações e teses, leitura em livros disponíveis nas bibliotecas virtual e física da Unitins, para assim proceder à fundamentação teórica do trabalho.

Na segunda etapa: realizou-se um levantamento de dados secundários, ou seja, checagem em documentos internos disponíveis na ADAPEC, Unidade Local e Abatedouro de Dianópolis, para identificar registros relacionados à dinâmica da cadeia produtiva da carne bovina no município. A terceira etapa: Visitas in loco a ADAPEC, de forma, identificar o responsável pela Unidade Local e assim formalizar por meio de ofício a solicitação do relatório descritivo com o quantitativo de cabeças de bovinos e de propriedades rurais de Dianópolis.

Na quarta etapa: a visitas in loco as residências dos produtores para o preenchimento de uma ficha de cadastro com os endereços de e-mails, números de telefones e WhatsAAp para posterior aplicação dos questionários. Na quinta etapa: foram realizadas entrevistas com 13 produtores rurais criadores de bovinos de Dianópolis, para identificar as estratégias adotadas no transporte de bovinos das propriedades até o local de abate. O questionário aplicado aos produtores foi estruturado, misto com dez questões, sendo quatro abertas e seis fechadas, enviado via e-mails com a utilização do formulário Google forms. A amostra da pesquisa de campo de 13 participantes representa 2,39\% do universo de 543 produtores.

Na sexta etapa: realizou-se visitas in loco as dependências do Abatedouro para conhecer a estrutura física e os processos de produção, o gestor responsável e solicitar autorização para a realização da pesquisa, a gerente disponibilizou o endereço de e-mails da empresa, número do telefone e WhatsAAp. Na sétima etapa: realizou-se a entrevista com a gerente responsável pelo Abatedouro, para conhecer o processo de produção da carne bovina, assim como, os meios de transporte utilizados na movimentação da carne do local de abate até o consumidor final.

O questionário aplicado a gerente foi semi-estruturando, com cinco questões abertas, enviado via $e$-mails com a utilização do formulário Google forms. Cabe ressaltar que, as entrevistas foram realizadas no período compreendido entre 10 a 30 de outubro de 2020. A oitava e última etapa: procederam-se à tabulação, análise e interpretação dos dados extraídos por meio dos questionários aplicados aos participantes da pesquisa, obedecendo ao método qualitativo e quantitativo.

A escolha dos participantes da pesquisa deu-se pelo papel privilegiado na condução de elementos que compõe o gerenciamento da cadeia produtiva da carne bovina no Município de Dianópolis, de forma que os resultados possam apresentar um bom panorama desse conjunto de ações. Como critério de inclusão levou-se em consideração, proprietários criadores de bovinos que comprovaram possuir propriedades no Município de Dianópolis, a gerente do Abatedouro que aceitaram participar da pesquisa voluntariamente e assinaram o Termo de Consentimento Livre Esclarecido.

\section{Resultados e Discussão}

A seguir serão apresentados os resultados da pesquisa que descreve a quantidade de propriedades e de cabeças de bovinos no Município de Dianópolis. Assim como a opinião dos produtores rurais e da gerente do Abatedouro local, sobre os procedimentos adotados no transporte dos bovinos, abate beneficiamento, processamento, comercialização e distribuição da carne até o cliente final.

Quadro-1: Quantidade de propriedades, produtores de bovinos e população de bovinos no Município de Dianópolis/TO.

\begin{tabular}{|c|c|c|}
\hline Propriedades Rurais com bovinos & Proprietários Rurais & População bovina \\
\hline 543 & 553 & 52.844 \\
\hline
\end{tabular}

Fonte: ADAPEC/TO, Regional de Taquatinga/Unidade de Dianópolis.

Os Gráficos abaixo apresentam os resultados dos questionários aplicados junto aos produtores rurais de Dianópolis. 
Research, Society and Development, v. 10, n. 3, e7610311545, 2020

(CC BY 4.0) | ISSN 2525-3409 | DOI: http://dx.doi.org/10.33448/rsd-v10i3.11545

Gráfico -1: Distância das propriedades de Dianópolis:

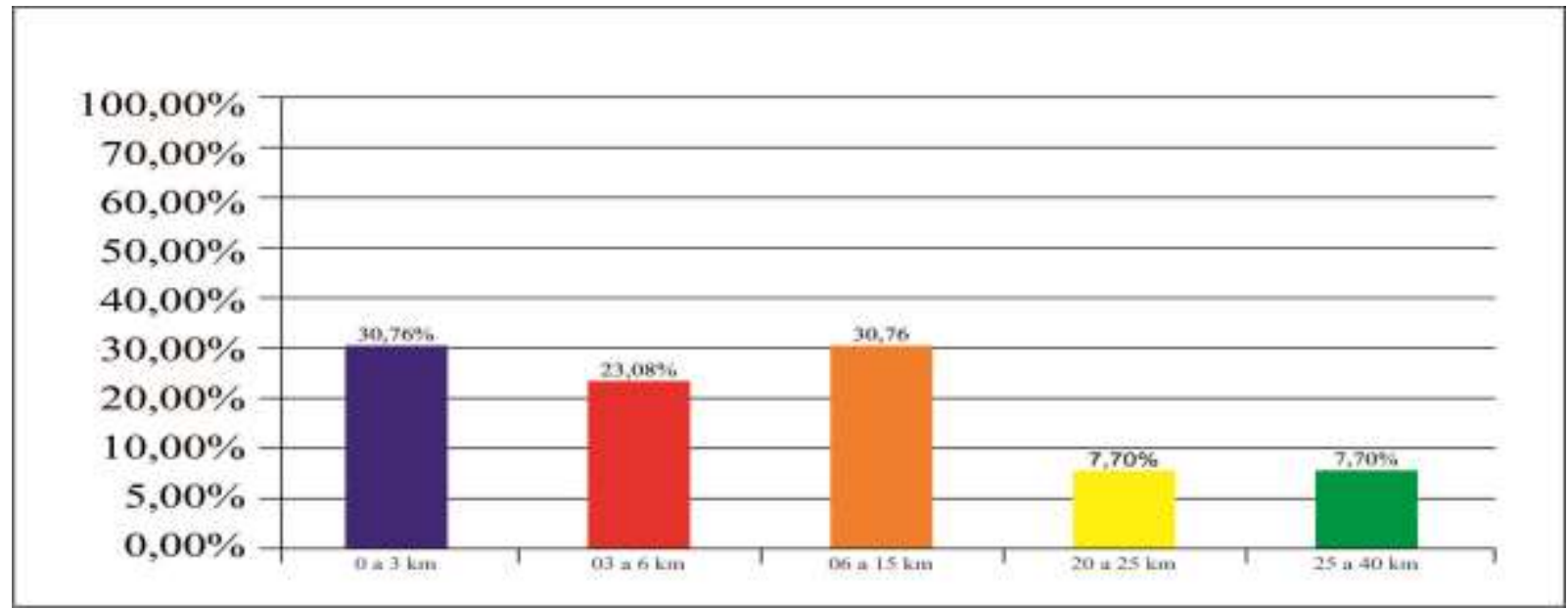

Fonte: Questionário produtores de Dianópolis /outubro /2020.

De acordo com o Gráfico acima, pode-se observar que a maioria absoluta das propriedades estão localizada na distância de três a 15 quilômetros do local de abate.

Gráfico -2: Quantidade de cabeças de gado dos produtores:

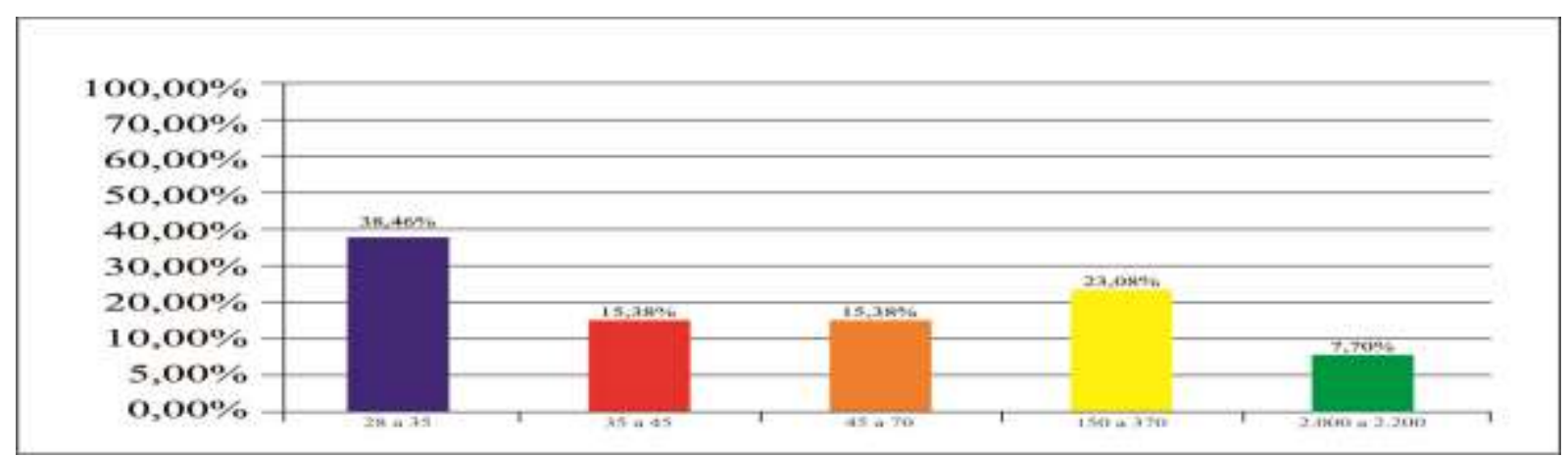

Fonte: Questionário produtores de Dianópolis /outubro /2020.

Conforme mostra o Gráfico acima, pode-se inferir que, a maioria absoluta dos produtores entrevistados, afirmaram que possuem um rebanho bovino de 28 a 370 cabeças.

Gráfico -3: Sexo dos produtores participantes da pesquisa:

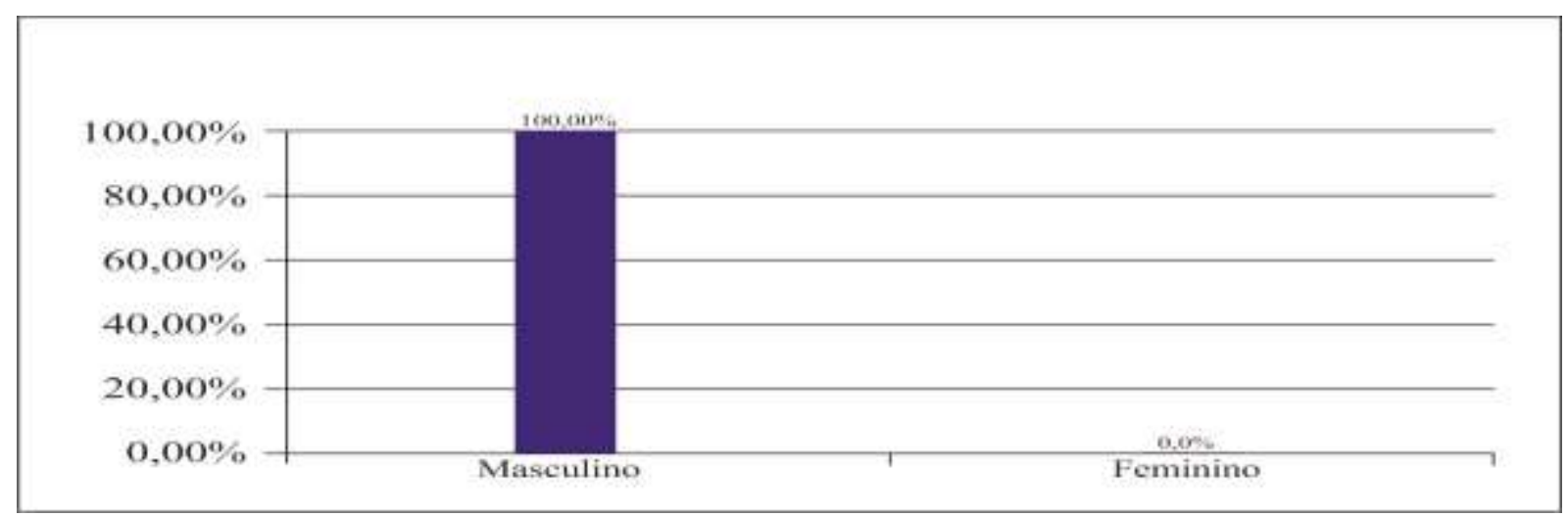

Fonte: Questionário produtores de Dianópolis /outubro /2020. 
Conforme mostra o Gráfico acima, pode-se afirmar que todos dos produtores entrevistados pertencem ao sexo masculino.

Gráfico -4: Faixa etária dos produtores:

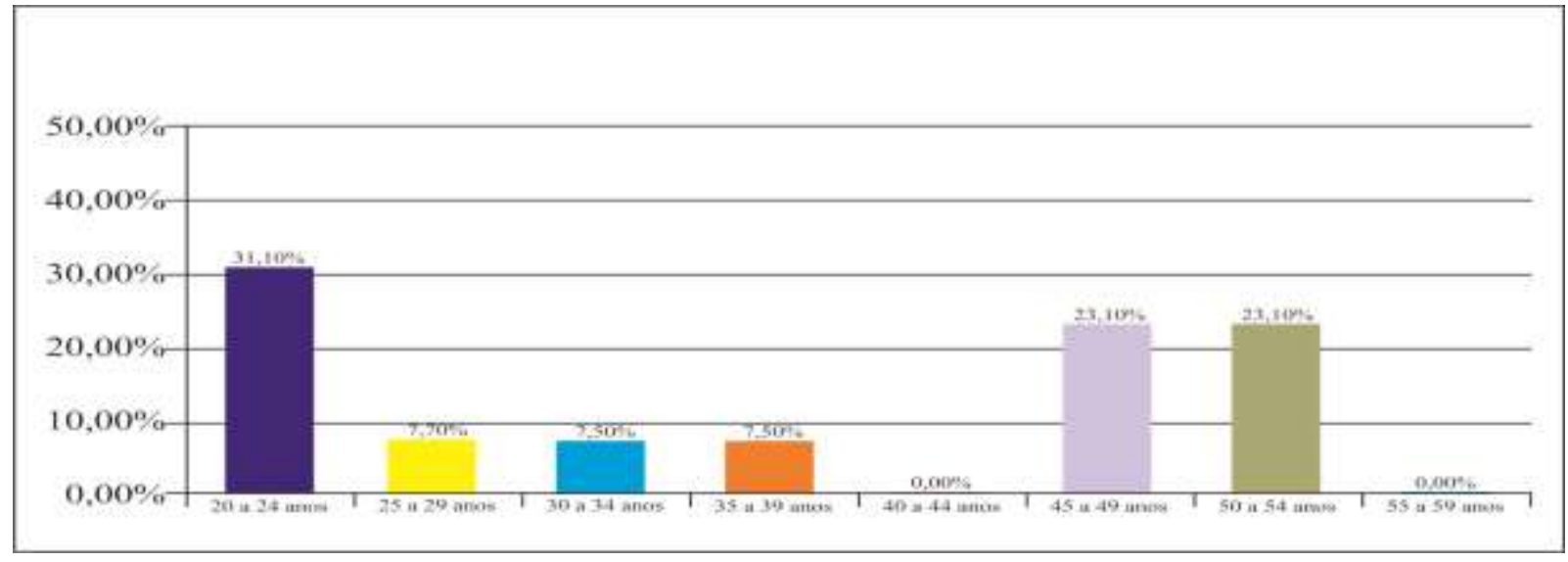

Fonte: Questionário produtores de Dianópolis /outubro /2020.

De acordo com o Gráfico acima, pode se observar que os produtores entrevistados são predominantemente jovens, ou seja, as faixas etárias estão bem distribuídas entre 20 e 49 anos.

Gráfico -5: Escolaridade dos produtores:

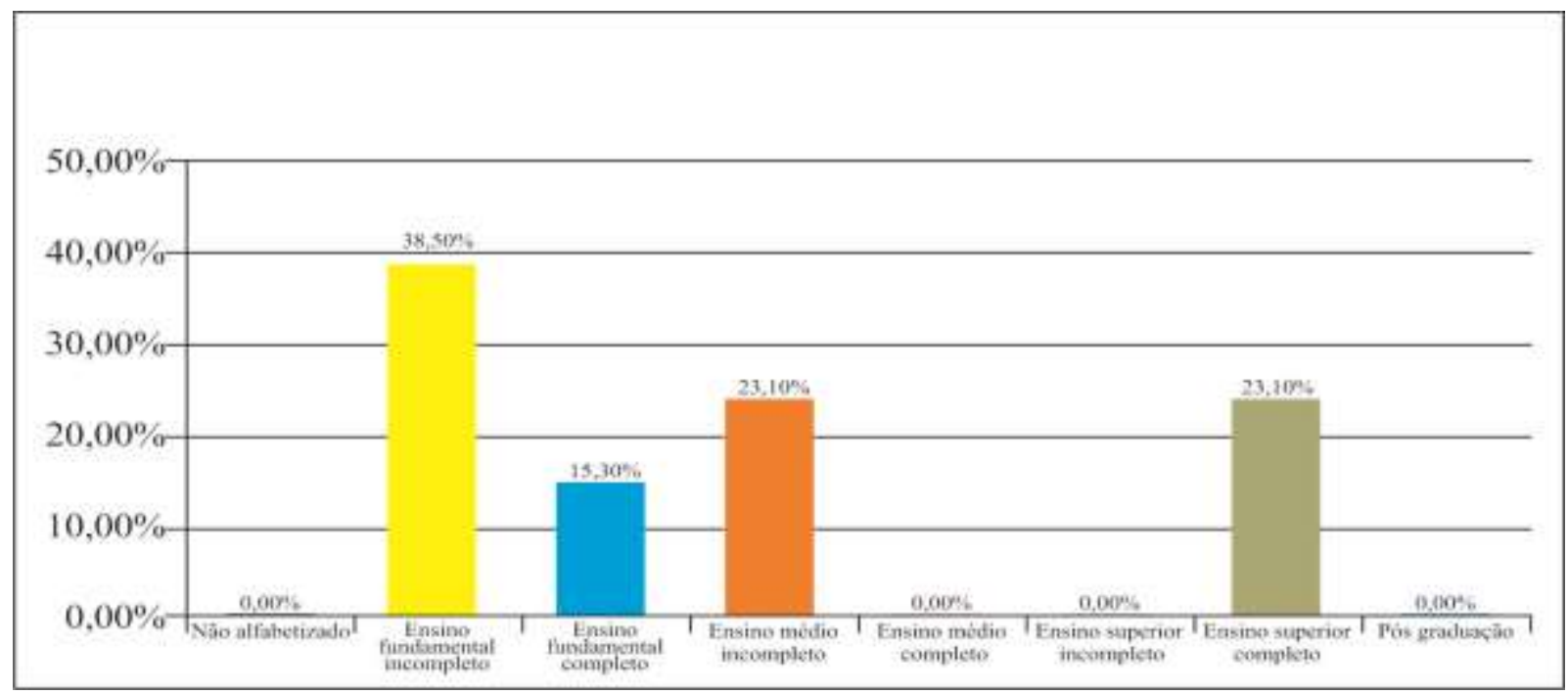

Fonte: Questionário produtores de Dianópolis /outubro /2020.

De acordo com o Gráfico acima, pode se inferir que, a maioria dos produtores entrevistados afirmaram que cursaram o ensino fundamental incompleto, completo e ensino médio incompleto. Por outro lado, observa-se que, os que um percentual significativo afirmou que possuem o ensino superior completo. 
Research, Society and Development, v. 10, n. 3, e7610311545, 2020

(CC BY 4.0) | ISSN 2525-3409 | DOI: http://dx.doi.org/10.33448/rsd-v10i3.11545

Gráfico -6: Procedimentos adotados antes da venda do bovino:

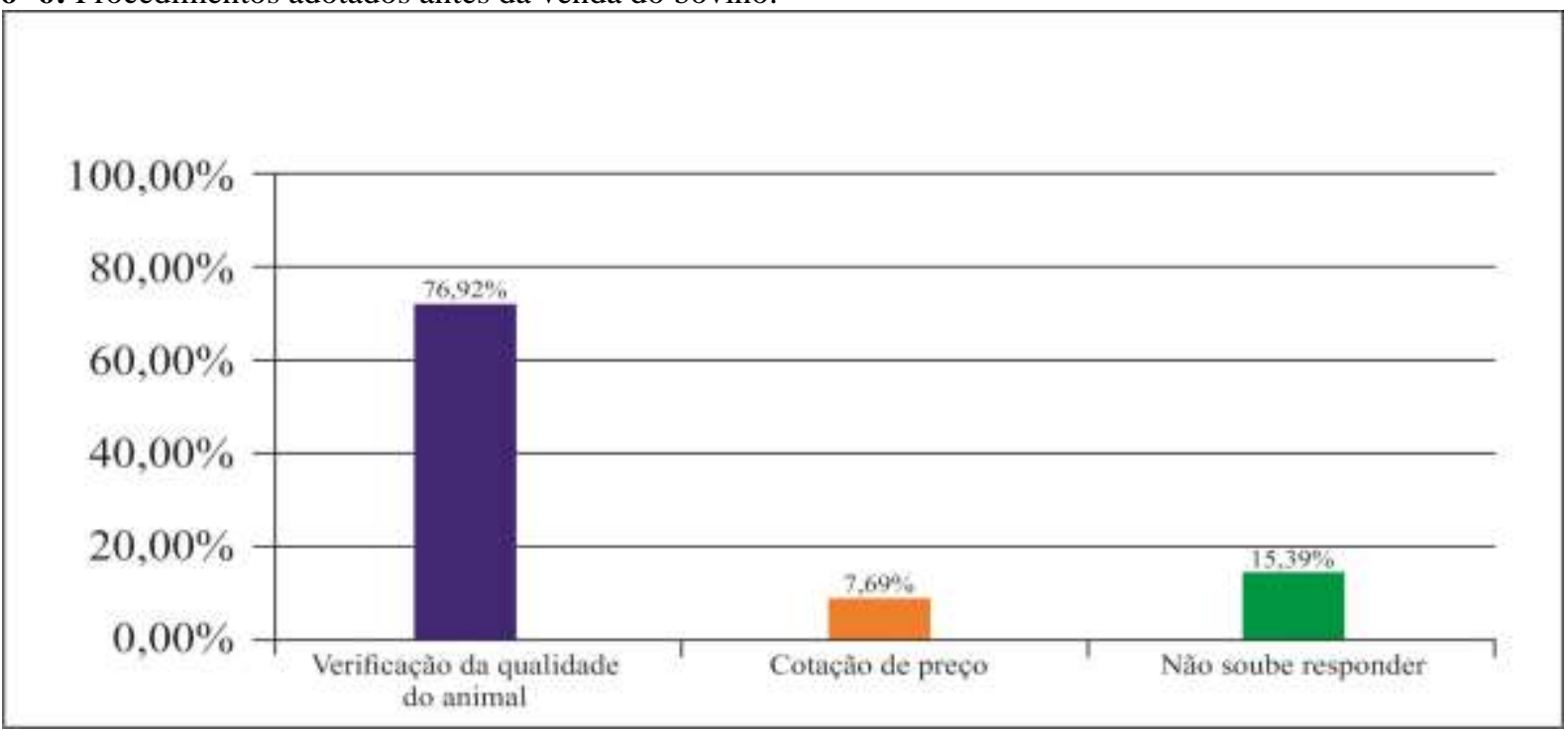

Fonte: Questionário produtores de Dianópolis /outubro /2020.

Conforme mostra ao Gráfico acima, pode-se afirmar que, a maioria dos produtores entrevistados, afirmaram que fazem a verificação das condições do animal antes da realização da venda. No entanto, é importante destacar que um percentual significativo, afirmaram que fazem a penas a cotação de preço e não souberam responder.

Gráfico -7: Destino dos bovinos das propriedades que comercializa para o abate:

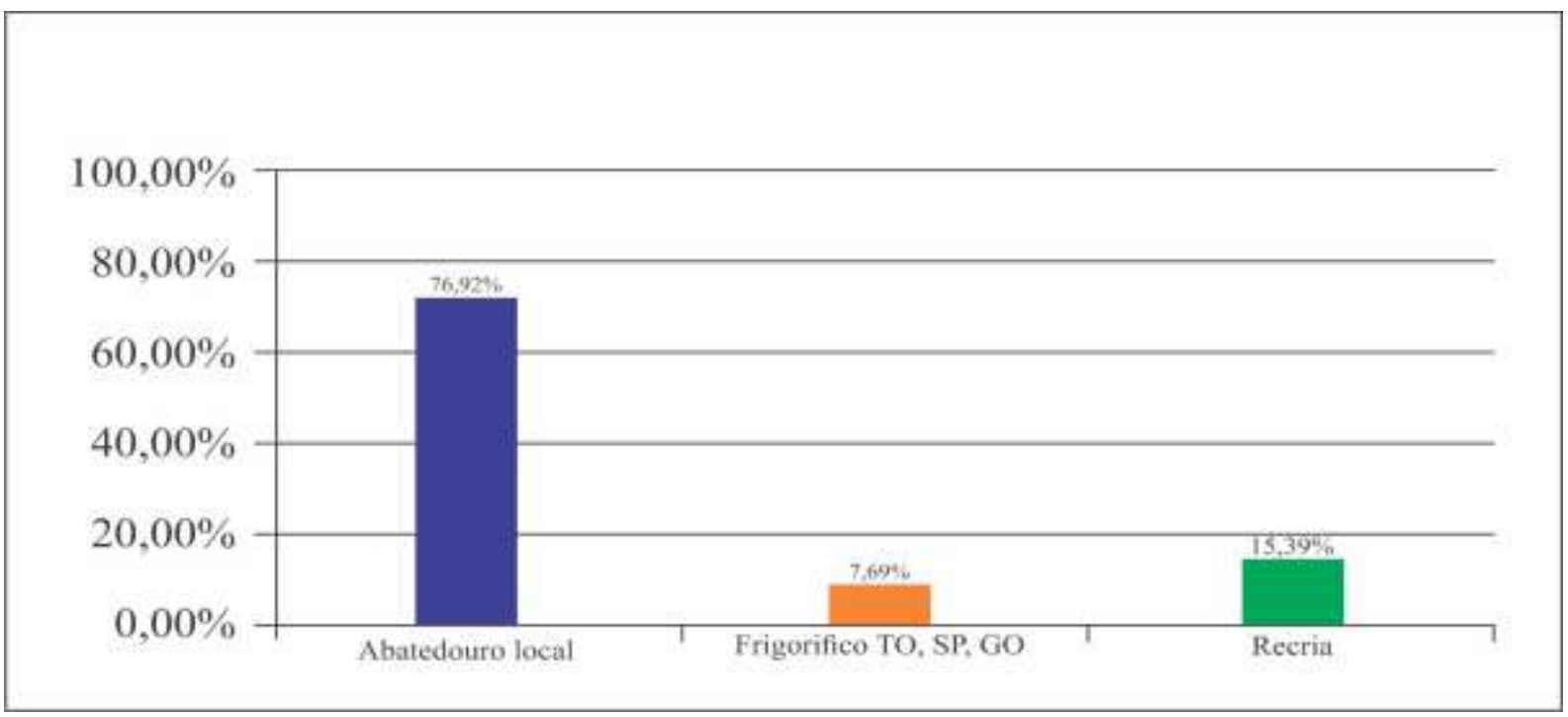

Fonte: Questionário produtores de Dianópolis /outubro /2020.

Conforme destaca o Gráfico acima, pode-se inferir que, a maioria dos entrevistados afirmaram que, os bovinos comercializados de suas propriedades têm como destino o frigorífico local. No entanto, um pequeno percentual, é vendido para frigoríficos de Goiás e São Paulo. 
Research, Society and Development, v. 10, n. 3, e7610311545, 2020

(CC BY 4.0) | ISSN 2525-3409 | DOI: http://dx.doi.org/10.33448/rsd-v10i3.11545

Gráfico -8: Tipo de veículo utilizado no transporte dos bovinos das propriedades ao local de abate:

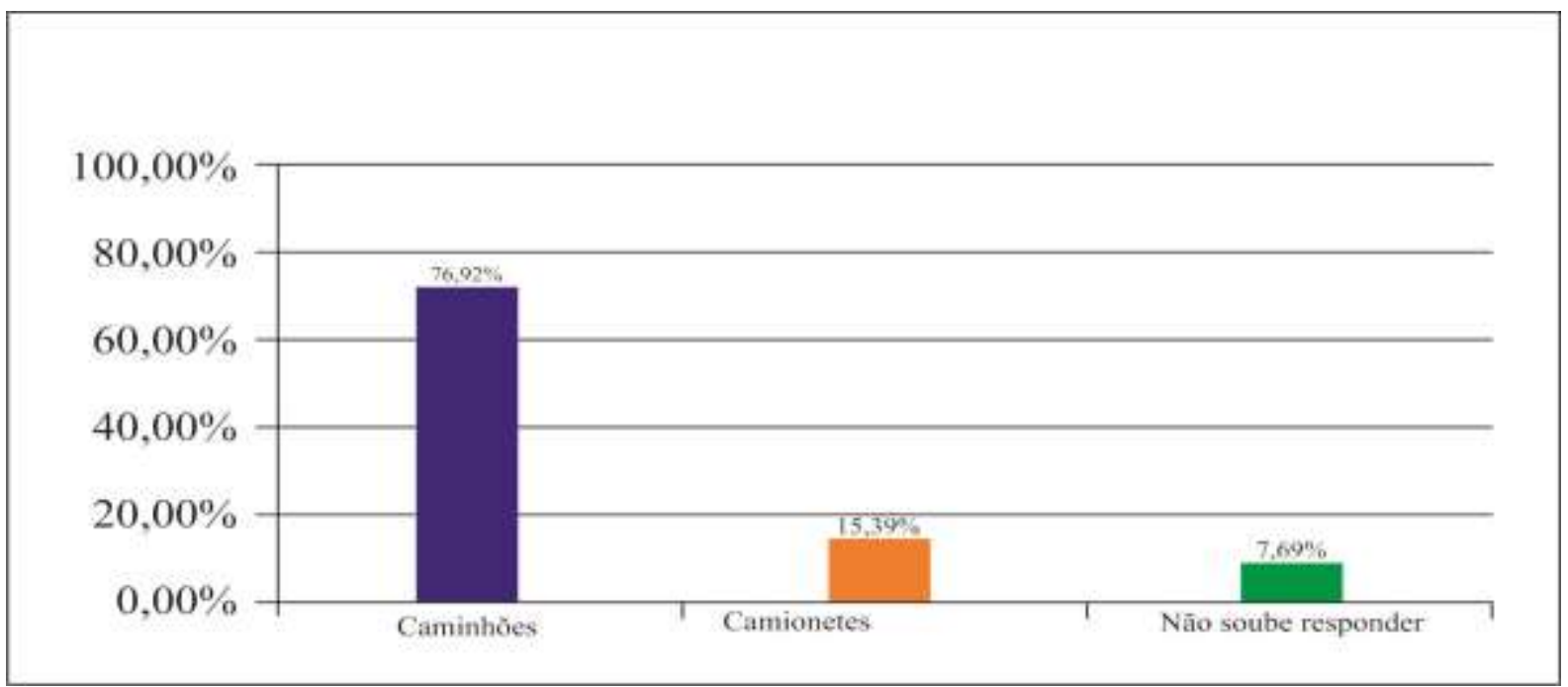

Fonte: Questionário produtores de Dianópolis /outubro /2020.

Conforme mostra o Gráfico acima, pode-se inferir que, a maioria absoluta dos produtores entrevistados, afirmaram que utilizam caminhões no transporte dos bovinos da propriedade para o local de abate. Por outro lado, um percentual significativo de produtores, afirmaram que utilizam camionetes, uma pequena parte não soube responder.

Gráfico-9: Como é feito o transporte dos bovinos das propriedades para o local de abate:

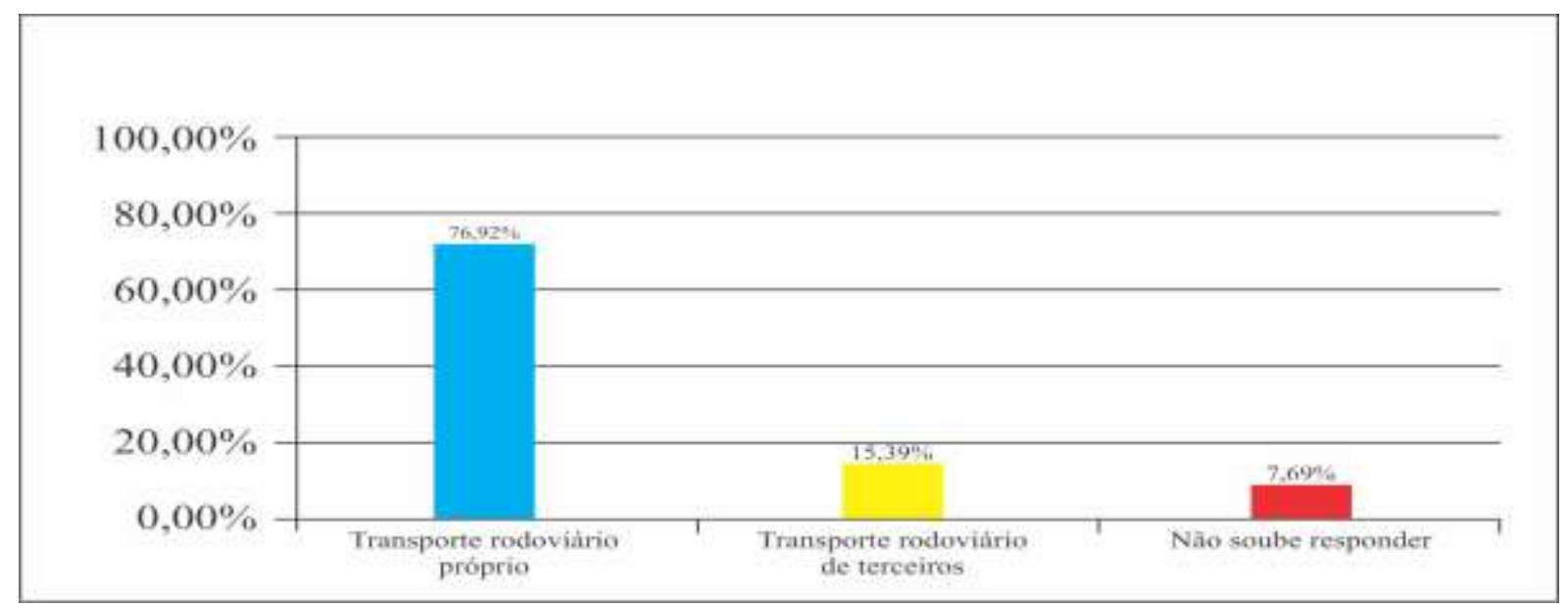

Fonte: Questionário produtores de Dianópolis /outubro /2020.

Conforme destaca o Gráfico acima, pode-se afirmar que, a maioria dos produtores entrevistados, responderam que utilizam o transporte rodoviário próprio no transporte dos bovinos da propriedade para o estabelecimento de abate. 
Research, Society and Development, v. 10, n. 3, e7610311545, 2020

(CC BY 4.0) | ISSN 2525-3409 | DOI: http://dx.doi.org/10.33448/rsd-v10i3.11545

Gráfico -10: As medidas de segurança que são tomadas antes do transporte dos bovinos das propriedades para o local de abate:

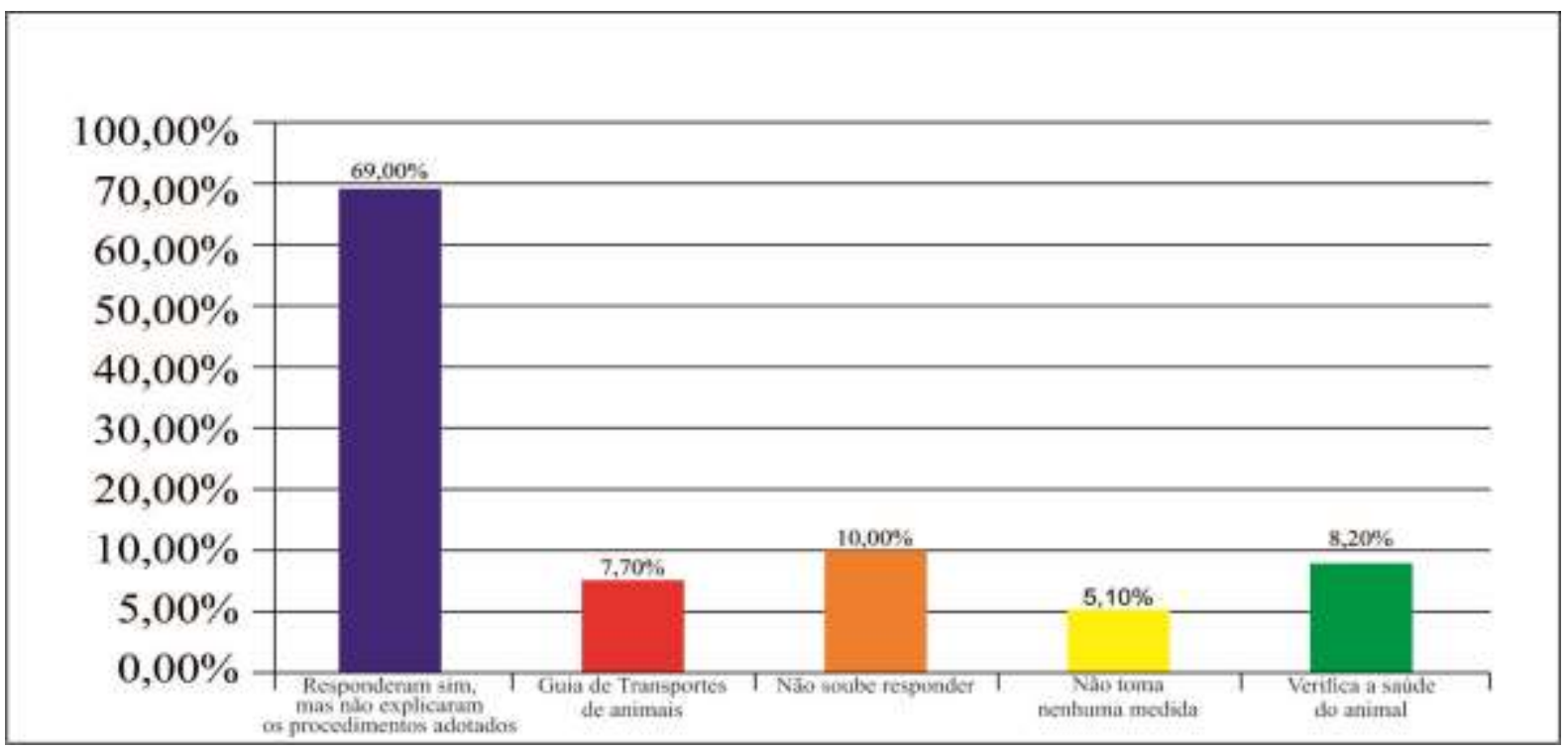

Fonte: Questionário produtores de Dianópolis /outubro /2020.

Conforme destaca o Gráfico acima, pode-se afirmar que, a maioria dos produtores entrevistados, responderam, mas não explicaram as devidas medidas de segurança que são tomadas antes do transporte dos bovinos da propriedade para o local de abate.

Diante dos resultados já expostos, a seguir serão apresentados os resultados da entrevista realizada com a gerente do matadouro de Dianópolis.

Sobre se o transporte dos bovinos de forma não adequada da propriedade ao estabelecimento de abate influencia na qualidade da carne, a gerente afirmou que:

[...] Influencia sim, a utilização do veículo não adequado para acomodação do animal, estradas esburacadas, os cuidados na condução do veículo, o estado que o animal entrou no caminhão para ser transportado, a duração da viagem e das condições do clima durante o trajeto pode contribuir para a carne ficar escura [...] (Abatedouro de Dianópolis /outubro /2020).

Sobre as medidas que são tomadas após o recebimento dos bovinos no abatedouro antes do abate, a gerente assim opinou:

[...] Os bovinos devem permanecer em repouso no curral e em jejum antes do abate para esvaziar o trato gastrointestinal facilitando a etapa de evisceração, reduzindo os riscos de contaminação da carcaça. Além disso, o animal é submetido ao um banho de jato de água para desestressar por causa do transporte. Estresse agudo do animal diminui a maciez da carne [...] (Abatedouro de Dianópolis /outubro /2020).

Em relação aos métodos que são adotados no manejo, pré-abate e no abate de bovinos, a gerente afirmou que:

[...] As práticas de manejo quando não são adequadas influenciam na qualidade da carne. O gado e levado até o box, lá o abate é feito com pistola que funciona com uma pressão de ar que ocasiona a morte cerebral do animal [...] (Abatedouro de Dianópolis /outubro /2020). 
No que se refere às etapas e processos de produção da carne bovina até a expedição do produto final, a gerente assim opinou:

[...] O processo de produção da carne bovina começa no transporte dos animais até a expedição do produto final, descanso, lavagem, pendura sangria, esfola, evisceração, cortes da carcaça, refrigeração, corte e desossa, embalagem, estocagem e expedição [...] (Abatedouro de Dianópolis /outubro /2020).

Sobre como ocorre à distribuição da carne bovina processada do abatedouro até o cliente final, a cliente afirmou que:

[...] À distribuição da carne ocorre no ato do pedido, em seguida inicia-se o processo de carregamento da carne no caminhão, logo em seguida inicia-se o a entregas nos locais de revendas, açougues e supermercados [...] (Abatedouro de Dianópolis /outubro /2020).

Diante do exposto, na seção seguinte são apresentados a análise e discussão dos resultados obtidos na pesquisa de campo realizada com os produtores rurais de Dianópolis, assim como do estudo de caso realizado no Matadouro local, onde realizou-se entrevista com a gerente do mesmo.

\section{Discussão dos Resultados}

Analisando os resultados da pesquisa de campo e do estudo de caso à luz dos elementos que compõe a gestão produtiva da carne bovina definidos como transporte dos bovinos das propriedades até o matadouro, procedimentos de abate, beneficiamento, processamento, comercialização e distribuição da carne até o cliente final, pode-se inferir que, a maioria das propriedades estão localizadas a uma distância média de 3 a 15 quilômetros do Matadouro de Dianópolis, uma vez que, a curto trajeto pode reduzir os risco de lesões e estresse dos bovinos.

Outra variável que chama atenção é o baixo quantitativo de bovinos por propriedade, com uma variação de 28 a 370 , cabeças, esse fator pode inviabilizar a venda de carga fechada e assim influenciar no aumento dos custos de transportes. No que se refere aos procedimentos adotados pelos produtores antes da venda dos bovinos, pode-se observar que um percentual significativo não adota medidas no sentido de examinar a saúde do animal, reduzindo a margem de segurança da qualidade da carne. Outro fator que merece destaque, é o fato da maioria dos bovinos serem comercializados para o abate no frigorífico de Dianópolis, a não entrada de compradores de outros municípios ou estados, pode gerar poder de barganha dos atravessadores locais e com isso reduzir a margem de lucro dos produtores.

Em relação ao tipo de veículo utilizado no transporte dos bovinos das propriedades ao local de abate, conforme mencionado nos questionários, os produtores utilizam caminhões camionetes e um pequeno percentual não souberam responder. Nota-se que os produtores não utilizam o Manual de Boas Práticas de Manejo, recomendado pelo Ministério da Agricultura.

No que se refere aos procedimentos adotados como medidas de segurança no transporte dos bovinos das propriedades para abatedouro foi mencionado pelos produtores entrevistados, que utilizam o transporte rodoviário próprio e de terceiros. No entanto, não explicaram os devidos procedimentos adotados na embarcação e no trajeto da viagem como medidas necessárias para reduzir os riscos de estresse, de ferimentos e de morte de animais durante as viagens.

Por outro lado, conforme mencionado pela gerente do Abatedouro de Dianópolis, o transporte dos bovinos de forma não adequada da propriedade ao local de abate influencia na qualidade da carne, de acordo com as falas da entrevistada, os caminhões devem passar por adaptações necessárias, os motoristas treinados em boas práticas de manejo no transporte e estarem atentos a todas as informações sobre a viagem. $\mathrm{O}$ abatedouro é periodicamente preparado para realizar o desembarque dos animais com agilidade e eficiência. 
Outra variável considerável são as medidas tomadas após o recebimento dos bovinos no abatedouro, antes do abate, após o desembarque, os bovinos permanecem em repouso no curral e em jejum para esvaziar o trato gastrointestinal e posteriormente submetido ao um banho de jato de água para desestressar. Estresse agudo do animal diminui a maciez da carne.

Em relação aos métodos que são adotados no abate de bovinos, conforme as falas da gerente, depois da lavagem, são realizadas as etapas de processos de insensibilização para deixar o animal inconsciente até o fim da sangria, para que ele seja abatido sem causar dor e sofrimento, de acordo com as leis de abate humanitário. $\mathrm{O}$ abate é feito com pistola que funciona com uma pressão de ar que ocasiona a morte cerebral do animal.

Sobre as estratégias de comercialização e distribuição da carne bovina processada no abatedouro. Conforme as falas da gerente, a comercialização da carne produzida no Abatedouro de Dianópolis, ocorre no ato do pedido, em seguida inicia-se o processo de carregamento no caminhão, na sequência as entregas nos locais de revendas, ou seja, açougues e supermercados. No entanto, a entrevistada não mencionou as alianças mercadológicas que orientam as regras das transações de compras, vendas e distribuição da carne ao cliente final.

\section{Considerações Finais}

Este trabalho possibilitou entender como ocorrem na prática todas as etapas dos processos de gestão da cadeia produtiva da carne bovina no Município de Dianópolis/TO, desde os insumos básicos até a transformação no produto e entrega ao cliente final. Com isso, pôde-se perceber a ineficiência em algumas etapas da cadeia produtiva da carne bovina que pode gerar desequilíbrio e assim afetar a lucratividade dos produtores.

Dessa forma, o objetivo central da pesquisa foi o de estudar a gestão da cadeia produtiva da carne bovina do Município de Dianópolis/TO, a partir da análise das atividades de transporte, beneficiamento, processamento, comercialização e distribuição até o cliente final, no período compreendido entre $1^{\circ}$ de fevereiro a 30 de outubro de 2020. Inicialmente, requereu-se a Unidade local da ADAPEC, o relatório descritivo com quantidade do rebanho bovino e de propriedades rurais do município. Observou-se um número pouco representativo de bovinos 52.844 , ou seja, $0,66 \%$ da população bovina do Tocantins, que conta com 8 milhões de cabeças nos 139 municípios. Para uma compreensão da realidade dos produtores sobre as estratégias adotadas no transporte de bovinos, recorreu-se a visitas in loco as residências dos mesmos, solicitou-se o preenchimento de uma ficha de cadastro com os endereços de e-mails, números de telefones e WhatsAAp para posterior aplicação dos questionários via a ferramenta Google forms. Posteriormente, realizou-se visitas in loco as dependências do Abatedouro para assim conhecer a estrutura física e o processamento de produção e solicitar a gerente a autorização para a realização da pesquisa, que disponibilizou o endereço de e-mails, número do telefone e WhatsAAp para aplicação do questionário via a ferramenta Google forms.

Dessa forma, o objetivo proposto foi atingido e pode-se responder à pergunta apresentada no início deste trabalho (Como ocorrem às atividades de transporte, beneficiamento, processamento, distribuição e comercialização da carne bovina no Município de Dianópolis/TO?). Nesse estudo, constatou-se que, a gestão da cadeia produtiva da carne bovina no Município de Dianópolis, apresenta-se alguns gargalos inerentes ao transporte e produção que passam despercebidos pelos produtores locais e pela gerência do Abatedouro, tudo isso, poderá contribuir para a perda de forças competitivas, inviabilizando a entrada em outros mercados consumidores.

A hipótese levantada no início deste trabalho foi (As atividades de transporte da propriedade até o abatedouro, o beneficiamento, processamento, comercialização e distribuição da carne bovina no Município de Dianópolis/TO, até o cliente final ocorre de acordo com as normas estabelecidas pelos órgãos de controle e fiscalização) não foi respondida totalmente, pois, foi possível notar que, tanto os produtores entrevistados, quanto a gerente do Abatedouro, não mencionaram a necessidade da aplicação de normas técnicas estabelecidas pela ADAPEC/TO e Ministério da Agricultura e Pecuária, que 
Research, Society and Development, v. 10, n. 3, e7610311545, 2020 (CC BY 4.0) | ISSN 2525-3409 | DOI: http://dx.doi.org/10.33448/rsd-v10i3.11545

obrigam a adoção das boas práticas de manejo durante o transporte de bovinos que visa reduzir as situações de risco que prejudicam o bem-estar dos animais e causam perdas quantitativas e qualitativas da carne. Assim como, a utilização de um manual de inspeção com a discrição de todos os procedimentos que devem ser adotados pelos colaboradores nos momentos do início ao fim do abate, até a entrega da carne ao cliente final para garantir produtos com certificação sanitária ao consumidor.

Portanto, com o término deste trabalho, foi possível identificar elementos que podem ser aprofundados em pesquisas futuras. Nesse sentido, recomenda-se que sejam executadas pesquisas científicas e trabalhos acadêmicos, para analisar com maior profundidade as variáveis que compõem o processo de gestão da cadeia produtiva da carne bovina na Região Sudeste do Tocantins. Estes elementos podem servir de parâmetro para o desenvolvimento de políticas para o incentivo da adoção de boas práticas no transporte de animais no Município de Dianópolis, apesar da necessidade da continuidade da pesquisa e a ampliação do número de produtores envolvidos.

\section{Referências}

Adapec, (2020). Agência de Defesa Agropecuária do Tocantins (Unidade Local de Dianópolis). Relatório Descritivo do quantitativo de bovinos, produtores e propriedades do Município de Dianópolis, agosto/2020.

Ballou, R. H. (1993). Logística Empresarial: transportes, administração de materiais e distribuição física: Atlas.

Ballou, R. H. (2012). Logística Empresarial - Transportes, Administração de Materiais e Distribuição Física: Atlas.

Batalha, M. O. (1995). As cadeias de produção agroindustriais: uma perspectiva para o estudo das inovações tecnológicas. Revista de Administração, São Paulo, (30), 42, 43-50. http://www.spell.org.br/documentos.

Batalha, M. O. (1997). Gestão Agroindustrial: Atlas.

Castro, L. H. (2009). Arranjo produtivo local: SEBRAE.

CNA. (2016). Confederação da Agricultura e Pecuária do Brasil. Produção de Carne bovina no Brasil em 2016. https://www.cnabrasil.org.br.

CNT (2017). Confederação Nacional do Transporte. Transporte rodoviário: desempenho do setor, infraestrutura e investimentos. - Brasília: CNT, 2017. http://cms.cnt.org.br/Imagens.

Corrêa, H. L., \& Corrêa, C. A. (2011). Administração de produção e operações: manufatura e serviços: uma abordagem estratégica.(2ª ed.): Atlas, 2011. 690 p.

Corrêa, H. L., Gianesi, I. G. N., \& Caon, M. (2008). Planejamento, programação e controle da produção. MRPII/ERP, conceitos, uso e implantação, base para SAP, Oracle Applications e outros softwares integrados de gestão. (5 ${ }^{\text {a }}$. ed.): Atlas.

Duarte, G. (2011). Dicionário de Administração e Negócios. Kindle Book Br, 2011.

Embrapa (2020). Manual de qualidade da carne do campo à mesa. https://www.embrapa.br/qualidade-da-carne/carne-bovina/transporte.

Fernandes, J. R., \& Neves, M. F. (2018) (Coordenadores). Federação das Indústrias do Estado do Tocantins. Plano Estratégico para as cadeias produtivas do agronegócio no estado do Tocantins, 2018-2027: Sistema FIETO.

Filho, A. D. B., \& Silva, I. J. O. (2004). Abate humanitário: ponto fundamental do bem-estar animal. Revista nacional da carne. São Paulo, (328) 36-44. https://www.sna.agr.br/revista-nacional-da-carne-alimentos.

Harding, H. A. (1981). Administração da Produção. (1ª edição): Atlas.

IBGE (2018). Instituto Brasileiro de Geografia e Estatística. Produção da Pecuária Municipal. https://www.ibge.gov.br/estatisticas/economicas/agricultura-epecuaria.

Kondo, A. A. (2007). Gerenciamento de Rastreabilidade em Cadeias Produtivas Agropecuárias: Dissertação apresentada ao Instituto de Computação, Unicamp, Campinas, maio de 2007. https://www.unicamp.br/unicamp/Dissertações/Downloads/ Kondo.

Machline, C. (1992). O modelo de custo mínimo na administração da produção. Revista de administração de empresa: RAE, 33 (2) $76-89$.

Malafaia, C. G., Costenaro, M. A., \& Camargo, M. E (2009). Atitudes de coordenação de produtores rurais na cadeia da carne bovina: o caso do Cite 120. Organizações Rurais \& Agroindustriais, Lavras, 11 (3) 393-406. https://www.redalyc.org/pdf.

Ministério da Agricultura, Pecuária e Abastecimento. Boas práticas de manejo, transporte/ Ministério da Agricultura, Pecuária e Abastecimento. Secretaria de Desenvolvimento Agropecuário e Cooperativismo. - Brasília: MAPA/ACS, 57 p. https://www.gov.br/agricultura/pt-br.

Ministério da Agricultura, Pecuária e Abastecimento/Secretaria de Política Agrícola, Instituto Interamericano de Cooperação para a Agricultura. Cadeia produtiva da carne bovina. Antônio Márcio Buainain e Mário Otávio Batalha (coordenadores): IICA: MAPA/SPA. http://repiica.iica.int/docs/.pdf. 
Research, Society and Development, v. 10, n. 3, e7610311545, 2020

(CC BY 4.0) | ISSN 2525-3409 | DOI: http://dx.doi.org/10.33448/rsd-v10i3.11545

Novaes, A. G. (2007). Logística e Gerenciamento da Cadeia de Distribuição: estratégia, operação e avaliação. (3 ${ }^{\mathrm{a}}$ ed.): Elsevier.

Roça, R. O. (2002). Abate humanitário de bovinos. In: Conferência virtual global sobre produção orgânica de bovinos de corte, 1, 2002, Botucatu. Anais... Botucatu: Universidade Estadual Paulista "Julio de Mesquita Filho".1-15. http://www.pubvet.com.br/uploads.

Russomano, V. H. (1979). Planejamento e acompanhamento da produção: Pioneira.

Silva, L. C. da. (2005). Cadeia Produtiva de Produtos Agrícolas. Universidade Federal do Espírito Santo: Departamento de Engenharia Rural. Boletim Técnico: MS: 01/05 em 21/04/2005. https://ensus2009.paginas.ufsc.br.

Slack, N., Chambers, S., \& Johnston, R. (2009). Administração da produção. (3 ${ }^{\mathrm{a}}$. ed.): Atlas.

Staatz, J. M. (1997). Notes on the use of subsector analysis as a diagnostic tool for linking industry and agriculture. Michigan State University, 1997. Agricultural Economics Working Paper, 97-04.

Tirado, G. (2009). Demandas tecnológicas da cadeia produtiva da carne bovina: uma analise no Estado de São Paulo. Universidade de Brasília. Brasília.

Tubino, D. F. (2000). Manual de Planejamento e Controle da Produção: Atlas.

Tubino, D. F. (2007). Planejamento e controle da produção, teoria e prática. (1 ${ }^{\mathrm{a}}$. ed.): Atlas.

Valente, A., Passaglia, E., \& Novaes A.G. (2001). Gerenciamento de Transporte e Frotas: Pioneira Thomson Learning.

Zylbersztajn, D., \& neves, M. F. (2000). (Org.). Economia e gestão dos negócios agroalimentares: indústria de alimentos, indústria de insumos, produção agropecuária, distribuição: Pioneira, 428 p. 